\title{
Chronic Enterocyte Infection with Coronavirus
}

\section{One Possible Cause of the Syndrome of Tropical Sprue?}

\author{
S.J. BAKER, MD, (MELB), FRACP, FRCP(C), M. MATHAN, MD(MAD), V.I. MATHAN, MD \\ (MAD), PhD, S. JESUDOSS, MSc. and S.P. SWAMINATHAN
}

Pleomorphic coronavirus-like particles have previously been observed in the feces of a number of apparently healthy south Indian subjects, and in those with tropical sprue (1). This communication describes the finding of coronavirus-like particles in the jejunal epithelial cells of an individual with malabsorption, who was excreting large numbers of these particles in his stools.

\section{CASE REPORT}

Daily fecal fat excretion was measured by the method of van de Kamer et al (2) while the patient was on a $50 \mathrm{-g}$ fat intake and the results expressed as a three-day running mean, normal being less than $5 \mathrm{~g} /$ day. The 5 -hr urinary excretion of xylose, after a 5-g oral dose, was measured by the method of Roe and Rice (3), normal excretion being $25 \%$ of the dose or more. Vitamin $\mathrm{B}_{12}$ absorption following a $1-\mu \mathrm{g}$ dose of $\left[{ }^{57} \mathrm{Co}\right]$ vitamin $B_{12}(0.5 \mu \mathrm{Ci})$ was estimated by measuring plasma radioactivity $8 \mathrm{hr}$ after the dose, normal values being $0.2 \%$ of the dose per liter of plasma or more (4). Jejunal biopsy was carried out using a Crosby capsule (5) positioned under radiological control. Tissue for electron microscopy was immediately placed in Dalton's fixative (6) at $4^{\circ} \mathrm{C}$ and processed as described previously (7). Negatively stained stool extracts (1) and tissue sections were examined under a Phillips EM200

\footnotetext{
Manuscript received June 26, 1981; revised manuscript received February 4, 1982; accepted February 24, 1982.

From the Wellcome Research Unit, Christian Medical College \& Hospital, Vellore-632004, Tamil Nadu, India.

Dr. Baker's present address is St. Boniface Hospital, 409 Tache Avenue, Winnipeg, Manitoba, Canada R2H 2 A6.

Supported by the Wellcome Trust and the World Health Organization.

Address for reprint requests: Dr. S.J. Baker, St. Boniface Hospital, 409 Tache Avenue, Winnipeg, Manitoba, Canada R2H $2 \mathrm{~A} 6$.
}

electron microscope. Jejunal aspirates were cultured for bacteria both aerobically and anerobically (8).

The patient, $\mathrm{Mu}$, was a 47 -year-old Indian male. A number of years previously he had developed symptoms of a duodenal ulcer. At the age of 34 he had undergone a vagotomy and gastrojejunostomy at another hospital. Since the operation he had never really been completely well and had suffered from intermittent attacks of abdominal pain and vomiting and occasional episodes of diarrhea. Two months before admission his diarrhea became much worse, and he started to pass 16-20 watery or semifluid stools per day. Physical examination showed obvious weight loss, an old right upper paramedian abdominal scar, but no other abnormalities.

Repeated microscopic examination of the stools and of jejunal aspirates showed no evidence of parasitic infestation, and stool cultures grew no enteric pathogens. Stool fat excretion varied from 20 to $41 \mathrm{~g} /$ day. Urinary xylose excretion, done on a number of occasions, varied from 7 to $12 \%$ of the dose. Vitamin $B_{12}$ absorption was abnormal when tested both without and with added intrinsic factor $(0.01 \%$ and $0.04 \%$ of the dose per liter of plasma, respectively). Serum immunoglobulins were in the normal range. Barium meal examination showed the presence of a deformed duodenal cap, a functioning gastrojejunostomy, and moderate dilatation of the duodenum and upper jejunal loops. A biopsy taken from the efferent jejunal loop, examined by light microscopy, showed slight reduction in the overall thickness of the mucosa, a moderate degree of glandular hypertrophy, an increased cellularity of the lamina propria, and a marked increase in intraepithelial lymphocytes. Aspirates taken in the fasting state from both the afferent and efferent loops, showed $10^{7}$ bacteria/ml of fluid, coliforms being the predominant organism.

The patient was rehydrated and, after investigation, a two-week course of oral tetracycline, $250 \mathrm{mg} 6$ hourly, was given with little symptomatic relief and no change in his steatorrhea, xylose excretion, or vitamin $\mathrm{B}_{12}$ absorption. He was then treated symptomatically with antidiarrheal agents (tincture belladonna and tincture of opium). He was followed over a period of eight months, his 


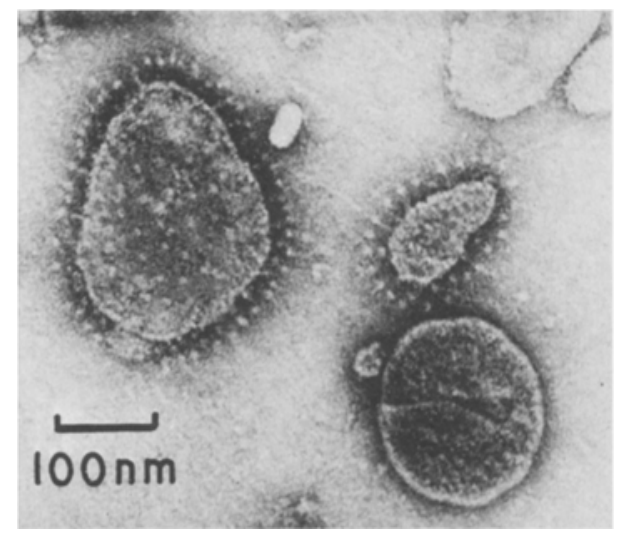

Fig 1. Two typical fringed particles from the stool of $\mathrm{Mu}$ as seen by negative staining.

general condition gradually improved although his steatorrhea, poor xylose absorption, and vitamin $\mathrm{B}_{12}$ malabsorption persisted.

Electron Microscopic Studies. Examination of the stools by electron microscopy showed large numbers of fringed particles, mostly round or oval-shaped (Figure 1), but occasional elongated or bizarre-shaped ones were also seen. The particles, including the fringe, varied in size from about 100 to about $400 \mathrm{~nm}$, with an occasional elongated form being up to $800 \mathrm{~nm}$ long. These particles were found repeatedly on each of 17 occasions that the stools were examined over the eight-month period of observation. At no time was there any evidence of antibody coating of the particles.

Tissue for electron microscopy was obtained from five jejunal biopsies, taken at different periods of time, from the efferent loop. In all the sections, from each of the biopsies, a number of the epithelial cells showed degenerative changes, including an overall pallor, swelling of the mitochondria, dilatation of the rough endoplasmic reticulum, increase in lysosomes and, in some cells, grouping of the microvilli. The degenerating cells were distributed in a patchy fashion both along the sides of the villi and in the crypts, interspersed between fairly normal looking epithelial cells (Figure 2). Occasional degenerating epithelial cells showed membrane-lined vesicles containing viruslike particles which were $50-100 \mathrm{~nm}$ in size (Figure 3 ). Some of these particles had a pale-staining central region while others showed dense core material; some showed a distinct double outer membrane and most had a peripheral fringe. In some vesicles there were areas of increased density adjacent to the lining membranes. Although the vesicles could be found in some sections from each of the biopsies, they were much more numerous and more easily found in sections from a biopsy taken four weeks after admission than in the others. No vesicles were found in any of the healthy looking cells.

A partially purified preparation of the virus particles was made by passing a stool suspension through a series of Millipore filters of decreasing pore size $(3,0.45$, and 0.3

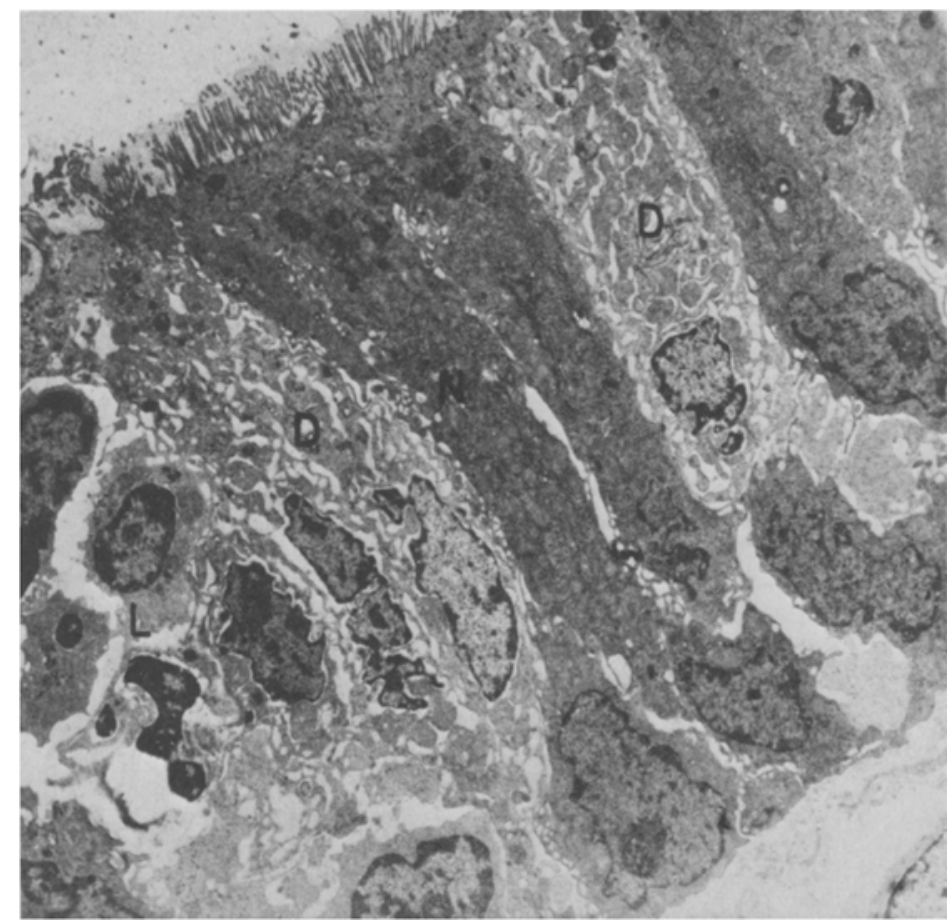

Fig 2. Jejunal biopsy of $\mathrm{Mu}$ showing crypt epithelial cells. Dark-staining normal epithelial cells $(\mathrm{N})$ with several pale-staining degenerating epithelial cells (D) and infiltrating lymphocytes (L) $(5000 \times)$. 


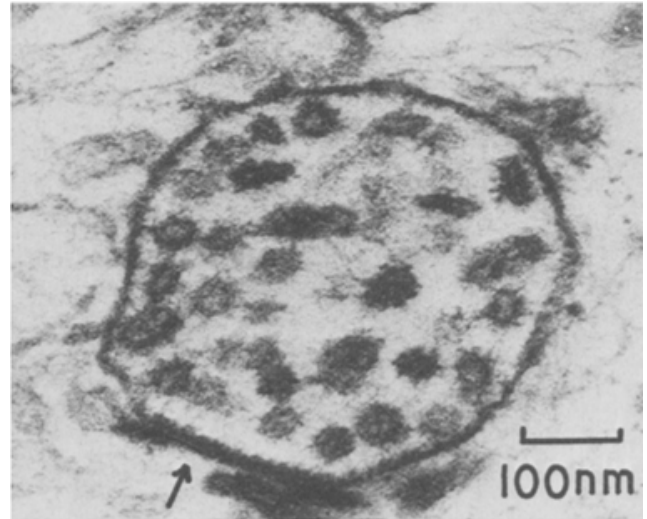

Fig 3. Vesicle containing coronavirus-like particles in a degenerating crypt cell from $\mathrm{Mu}$. The particles have a fringe, an outer double membrane (arrowheads), and a dense or translucent central area. At one point (arrow) there is accumulation of dense material adjacent to the lining membrane.

$\mu \mathrm{m}$, separated from each other by nylon net. When examined under the electron microscope, the resultant deposit was found to consist mainly of fringed particles with a small amount of fragments of bacterial flagellae and other debris. This was used as an antigen, and injected into rabbits at 2-week intervals. Three rabbits so injected produced complement-fixing antibodies in titres of $1: 32$ 1:128 when tested against this antigen. When this antiserum was added to fecal extracts, in a 1:20 dilution, electron microscopy showed marked clumping and coating of the coronavirus-like particles. The patient's serum did not have this effect, nor could complement-fixing antibodies be detected in the serum.

Repeated attempts to grow the virus in various cell lines and in human fetal intestinal organ culture have been unsuccessful.

\section{DISCUSSION}

Coronavirus infection has been implicated as causing gastroenteritis in pigs $(9,10)$, turkeys (11), calves $(12,13)$, dogs $(14,15)$, foals $(16)$, and rabbits (17). Fecal excretion of coronavirus by humans was previously described from this Unit, but the relation, if any, to disease was not clear (1). A similar finding was reported in children from Western Australia by Schnagl et al (18). Caul et al $(19,20)$ found coronavirus in fecal extracts from human subjects in three outbreaks of acute gastroenteritis and suggest that the virus may have been responsible for the illness.

The present case seems to be the first reported instance of the demonstration of coronavirus-like particles in human intestinal biopsy material. It should be noted that the intracellular morphology of the particles is similar to that of other human coronaviruses grown in tissue or organ culture (2022) and also to the intracellular appearance of intestinal coronavirus from calves $(13,23)$ and dogs (24).

It is noteworthy that virus was only evident in degenerating cells and that even within such cells, its distribution was very patchy. In sections from one of the biopsies they were plentiful, while in sections from others they were difficult to find and could easily have been missed. The size of the particles in the tissue sections were, on the average, smaller than those seen by negative staining of unfixed fecal extracts. A similar difference between the size of coronaviruses, as seen in tissue section, and in negatively stained preparations has been observed by Becker et al (21) and Bridger et al (23). This can probably be attributed, on the one hand, to some degree of shrinking during fixation and embedding, and, on the other hand, to collapse and flattening of the unfixed virus in the negatively stained preparations (21).

The present patient demonstrates that coronavirus-like particles can be excreted by an individual over a prolonged period of time. The facts that no antibodies could be detected in the serum of the patient, nor were any coated particles seen in stool extracts, suggest that the patient had not formed antibodies to the particles. This may, at least in part, explain the chronicity of the infection. This contrasts with intestinal infection with rotavirus where the virus is only excreted for a period of a few days (25) and where antibodies appear in the serum and can frequently be seen coating virus particles in fecal extracts $(26,27)$.

Since coronavirus-like particles can be found in the stools of many apparently healthy subjects in southern India (1), the mere demonstration of these particles in feces or jejunal biopsy material is inadequate evidence of their causative role in producing symptomatic gastrointestinal disease. However, this fact also does not exclude a possible pathogenetic role for the virus, since it is well established that many virus infections only produce symptomatic disease in a proportion of those infected. Moreover, there may be different strains of the virus, some of which are pathogenic and others which are not, even though they look alike.

In the present patient the demonstrated intestinal malabsorption could possibly have been due to the gastroenterostomy producing a stagnant bowel syndrome, even though treatment with tetracycline did not significantly affect the malabsorption. Howev- 


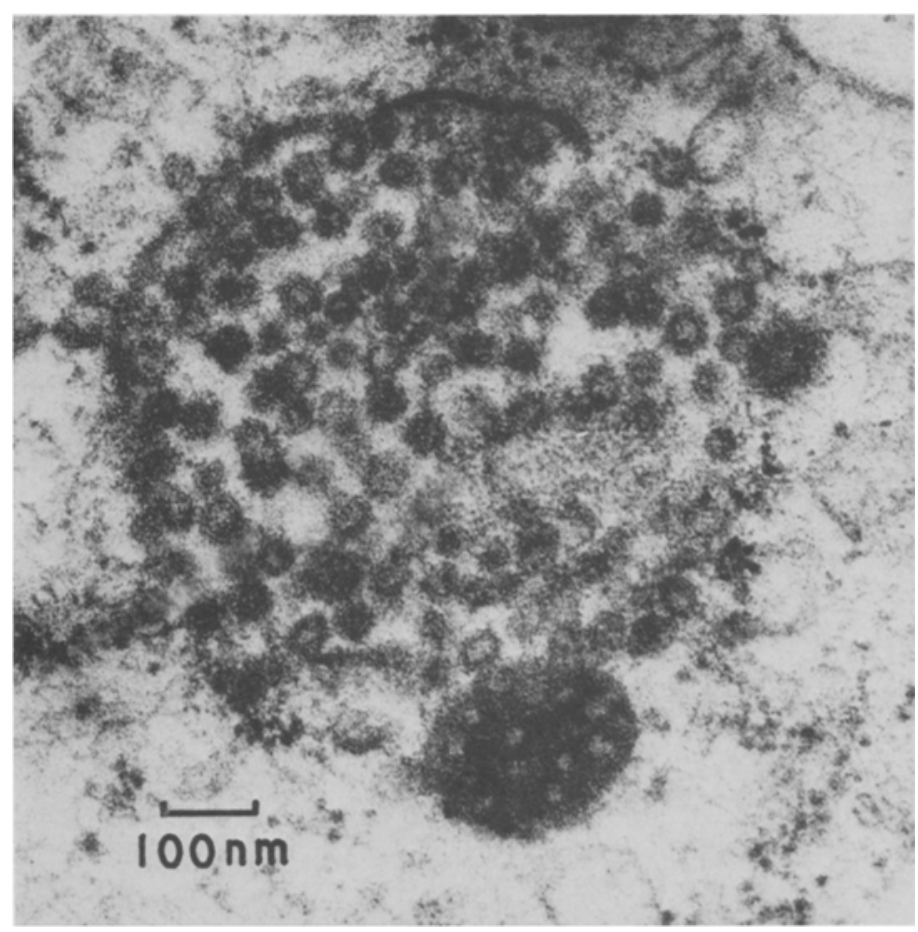

Fig 4. Vesicle, similar to that seen in Figure 3, in a degenerating enterocyte from patient Ky with classical chronic tropical sprue.

er, the ultramicroscopic structure of jejunal biopsies in the blind loop syndrome is usually normal (28) or, at most, mildly abnormal (29). In our patient the ultramicroscopic changes were very marked and are therefore difficult to ascribe to the gastroenterostomy. Since the virus-containing vesicles were only found in degenerating cells, it would seem reasonable to ascribe the cell damage to the presence of the virus. The alternative hypothesis, that the virus grows preferentially in cells already damaged by some other unknown agent, is less plausible. If the former hypothesis is correct, then it is probable that the coronavirus infection was responsible for the malabsorption.

The ultramicroscopic changes seen in the jejunal mucosa of this patient are very similar to those we reported in Indian patients with classical chronic tropical sprue (7). Careful review of previously collected electron micrographs from this study has revealed similar vesicles with coronavirus-like particles in biopsies from three of twelve patients with classical chronic tropical sprue (Figure 4) and also in one unpublished patient with a sprue-like syndrome associated with agammaglobulinemia. In view of the difficulty of finding the virus-like struc- tures in some of the biopsies from the present case, it seems probable that a more thorough search of multiple sections of biopsies from south Indian patients with tropical sprue may reveal a higher percentage of cases with ultramicroscopic evidence of coronavirus-like particles in the damaged enterocytes. Although much further work remains to be done, these findings support Manson-Bahr's hypothesis (30) and the accumulating epidemiological evidence (31) that at least one cause of the syndrome of tropical sprue (32) is a viral infection of the enterocytes.

\section{SUMMARY}

A man with a gastrojejunostomy and intestinal malabsorption was found to be excreting large numbers of coronavirus-like particles in his stools over a period of at least eight months. Coronaviruslike particles were found in vesicles in degenerating jejunal enterocytes in all of five jejunal biopsies. In a review of electron micrographs, similar structures were found in biopsies from three of 12 patients with classical chronic tropical sprue and in one patient with a sprue-like syndrome associated with 
agammaglobulinaemia. The hypothesis is advanced that infection with this virus may produce enterocyte damage and may be one cause of the syndrome of tropical sprue.

\section{ACKNOWLEDGMENTS}

We wish to thank Prof. C.K. Job and the Leprosy Mission for electron microscopy facilities, Mr. J. Prabhakaran for the photography, Mr. B. Joseph for technical assistance, and Miss B. Klym for secretarial assistance. We are grateful to Prof. Ian Holmes of the University of Melbourne, for his help and encouragement.

\section{REFERENCES}

1. Mathan M, Mathan VI, Swaminathan SP, Yesudoss S, Baker SJ: Pleomorphic virus-like particles in human feces. Lancet 1:1068-1069, 1975

2. van de Kamer JH, Huinink $H$ ten B, Weijers HA: Rapid method for the determination of fat in the feces. J Biol Chem 177:348-355, 1949

3. Roe JH, Rice EW: A photometric method for the determination of free pentoses in animal tissues. J Biol Chem 173:507512,1948

4. Mathan VI, Swarnabai S, Baker SJ: Intestinal absorption of radioactive vitamin B12: A comparison of plasma, fecal and urinary tests. Indian J Med Res 61:714-723, 1973

5. Crosby WH, Kugler HW: Intraluminal biopsy of the small intestine, the intestinal biopsy capsule. Am J Dig Dis 2:236241, 1957

6. Dalton AJ: A chrome osmium fixative for electronmicroscopy. Anat Rec 121:281, 1955

7. Mathan M, Mathan VI, Baker SJ: An electron microscopic study of jejunal mucosal morphology in control subjects and in patients with tropical sprue in southern India. Gastroenterology 68:17-32, 1975

8. Bhat P, Shantakumari S, Rajan D, Mathan VI, Kapadia CR, Swarnabai C, Baker SJ: Bacterial flora of the gastrointestinal tract in southern Indian control subjects and patients with tropical sprue. Gastroenterology 62:11-21, 1972

9. Mengeling WL, Booth AD and Ritchie AE:L Characteristics of a corona virus (strain $67 \mathrm{~N}$ ) of pigs. Am J Vet Res 33:297308, 1972

10. Pensaert MB, de Bouck P: A new coronavirus-like particle associated with diarrhea in swine. Arch Virol 58:243-247, 1978

11. Ritchie AE, Deshmukh DR, Larsen CT, Pomeroy BC: Electron microscopy of coronavirus-like particles characteristic of turkey bluecomb disease. Avian Dis 17:546-558, 1973

12. Mebus CA, Stair EL, Rhodes MB, Twienaus MI: Neonatal calf diarrhea: Propagation attenuation and characteristics of a corona virus-like agent. Am J Vet Res 84:145-150, 1973

13. Doughri AM, Storz J, Hajer I, Fernando HS: Morphology and morphogenesis of a corona-virus infecting intestinal epithelial cells of new born calves. Exp Mol Pathol 25:355370,1976

14. Keenan KP, Jervis HR, Marchwicki RH, Binn LN: Intestinal infection of neonatal dogs with canine coronavirus 1-71: Studies by virologic, histologic, histochemical and immunofluorescent techniques. Am J Vet Res 37:247-254, 1976

15. Takeuchi A, Binn LN, Jervis HP, Keenan KP, Hildebrandt PK, Valas RB, Bland FF: Electron microscope study of experimental enteric infection in neonatal dogs with a canine coronavirus. Lab Invest 34:539-549, 1976

16. Bass EP, Sharpee RL: Coronavirus and gastroenteritis in foals. Lancet $2: 822,1975$

17. Lapierre J, Marsolais G, Pilon P, Descôteaux J-P: Preliminary report on the observation of a coronavirus in the intestine of the laboratory rabbit. Can J Microbiol 26:12041208,1980

18. Schnagl RD, Holmes IH, Mackay-Scollay EM: Coronaviruslike particles in Aboriginals and non-Aboriginals in western Australia. Med J Aust 1:307-309, 1978

19. Caul EO, Paver WO, Clarke SKR: Coronavirus particles in feces from patients with gastroenteritis. Lancet 1:1192, 1975

20. Caul EO, Clarke SKR: Coronavirus propagated from patient with non-bacterial gastroenteritis. Lancet 2:953-954, 1975

21. Becker WB, Mcintosh K, Dees JH, Chanock RM: Morphogenesis of avian infectious bronchitis virus and related human virus (strain 229E). J Virol 1:1019-1027, 1967

22. Oshiro LS, Schieble JH, Lennette EH: Electronmicroscopic studies of coronaviruses. J Gen Virol 12:161-165, 1971

23. Bridger JC, Egglestone SI: Replication of an enteric bovine coronavirus in intestinal organ cultures. Arch Virol 57:4351,1978

24. Takeuchi A, Binn LN, Jervis HR, Keenan KP, Hildebrandt PK, Valas RB, Bland FF 3rd: Electron microscope study of experimental enteric infection in neonatal dogs with a canine coronavirus. Lab Invest 34:539-549, 1976

25. Bishop RE, Davidson GP, Holmes IH, Ruck BJ: Detection of a new virus by electron microscopy of fecal extracts from children with acute gastroenteritis. Lancet 1:149-151, 1974

26. Flewett TW, Bryden AS, Davies A, Woode GN, Bridger JC, Derrick JM: Relation between viruses from acute gastroenteritis of children and new born calves. Lancet 2:61-63, 1974

27. Kapikian AZ, Kim HW, Wyatt RG, Rodriguez WJ, Ross S, Cline WL, Parrot RH, Chanock RM: Reovirus-like agents in stools: association with infantile diarrhea and development of serologic tests. Science 185:1049-1053, 1974

28. Donaldson RMJ: Role of enteric microorganisms in malabsorption. Fed Proc 26:1426-1431, 1967

29. Ament ME, Shimoda SS, Saunders DR, Rubin CE: Pathogenesis of steatorrhea in three cases of small intestinal stasis syndrome. Gastroenterology 63:728-747, 1972

30. Manson-Bahr RH: Reflections on the etiology of tropical sprue, the present position. Z Tropenmed Parasit 8:174-180, 1952

31. Mathan VI, Baker SJ: Epidemiology of tropical sprue. In Tropical Sprue and Megaloblastic Anaemia, A Wellcome Trust Collaborative Study. London, Churchill Livingston, 1971, pp 159-188

32. Klipstein FA, Baker SJ: Regarding the definition of tropical sprue. Gastroenterology 58:717-721, 1970 